\title{
A first record of mussel, Septifer excisus (Wiegmann, 1837) (Bivalvia: Mytilidae) from Pakistan, Northern Arabian Sea
}

\author{
Ghazala Siddiqui and Sadar Aslam* \\ Centre of Excellence in Marine Biology, University of Karachi, Karachi-75270, Pakistan \\ *Correspondence: sadaraslam@gmail.com
}

\section{ABSTRACT:}

The live shells of mytilid mussel,Septifer excisus (Wiegmann, 1837) were collected from the rocks and oyster shells from Jiwani, Balochistan, Pakistan at neap tide from the intertidal zone.The observed specimens were straw to dark purple colour, attached to rocks and oyster shells by its' byssus threads; closely resemble Brachidontes species but a septum was found, below the beak inside the shell confirming the identification towards the byssally attached mytilid genus Septifer. Septifer excisus has significant difference with other members of the same genus by three characters: septum, beading ribs and posterior adductor scar. This species exists from Triassic to Holocene and has been recorded from many parts of the world. This is the first record from Jiwani, Balochistan, Pakistan.

Keywords:Arabian Sea, Bivalvia, Beading ribs, Jiwani, Mytilidae, Posterior Adductor Scar, Septifer excisus, Septum

\section{INTRODUCTION:}

Septifer excisus (Wiegmann, 1837)occur in tropic and sub-tropic seas in the intertidal zone to about 55m deep, attached by byssus, found attached to boulders at low tide [1]. The very first-time interpretation of the species was credited by Reeve [2] and Lamy's [3]. This species is fairly abundant in the Pleistocene deposits in Oahu [4]. These fossils were first identified as Septifer kraussii Kuster [5] but dissimilar to that species which were closely related to or included in the diversity of S. bilocularis [6]. The species is recorded in many parts of the world including Hawaii [6]; Raja Ampat Islands (RAI), Papua Province in Indonesia [7]; Guam, Mangilao [8]; Kenting National Park, Taiwan [9]; Andavadoaka, southwest Madagascar [10]; Pulau Semakau in Singapore [11]; Singapore [12]; Puerto Princesa City, Palawan, Philippines [13]; Australian IOT (Indian Ocean Territories) of Christmas Island in Indian Ocean and the Cocos in Keeling Island [14]; Mediterranean Sea [15]; West Malaysia, Singapore [16]; Qena, Egypt [17] and from Pakistan, in present study. To explore marine resources is very necessary to adore the nature's underworld beauty and precious wealthy resources.Pakistan comes under the list of countries having best marine resources including precious gems and metals (pearls, seadbed diamonds, offshore diamonds, gold), salt $(\mathrm{NaCl})$, major minerals (Bromine-> used in photography and disinfectants, Magnesium->used in agricultural chemical industries and construction), sedimentary rocks (limestone, sandstone, gypsum), phosphorous (used in agriculture), Sulphur (hydrothermal vents), fossil fuels (petroleum, coal, natural gas) and oil. Therefore, to discover and identify each of marine precious resources is also very necessary to know the marine status of flora and fauna. The present study was a first record which purely discovers the new species of sea mussel, Septifer excisus (Wiegmann, 1837) from Balochistan coast which is beneficial to other surrounding community by providing a friendly environment towards sessile animals especially oysters. This discovery will help nationally and 
internationally, as many of marine taxonomists and other researchers' to discover identify and report sea mussels from not only in Pakistan but all over the world.

Material and Methods:

Binocular, microscope, already reported images and previous literature were used to identify the specimens at species level.

\section{Classification}

Phylum: Mollusca

Class: Bivalvia

Subclass: Pteriomorpha

Order: Mytilida

Superfamily: Mytiloidea

Family: Mytilidae

Genus: Septifer

Species: Septifer excisus (Wiegmann, 1837)

Synonyms:Septifer fuscus (Récluz, 1848), Septifer troschelii (Dunker, 1853), Tichogonia excisa (Wiegmann, 1837), Tichogonia siamensis (Clessin, 1886), Septifer vaughani (DBR, 1938) ${ }^{18}$

Geologic time scale range:Triassic through Holocene

Study description:The live shells of mytilid mussel Septifer excisus (Wiegmann, 1837) were collected in January, 2017 from the rocks and oyster shells from Jiwani $\left(25.0473^{\circ} \mathrm{N}, 61.7459^{\circ} \mathrm{E}\right)$, Balochistan, Pakistan (Fig 1) at neap tide from the intertidal zone (Fig 1).

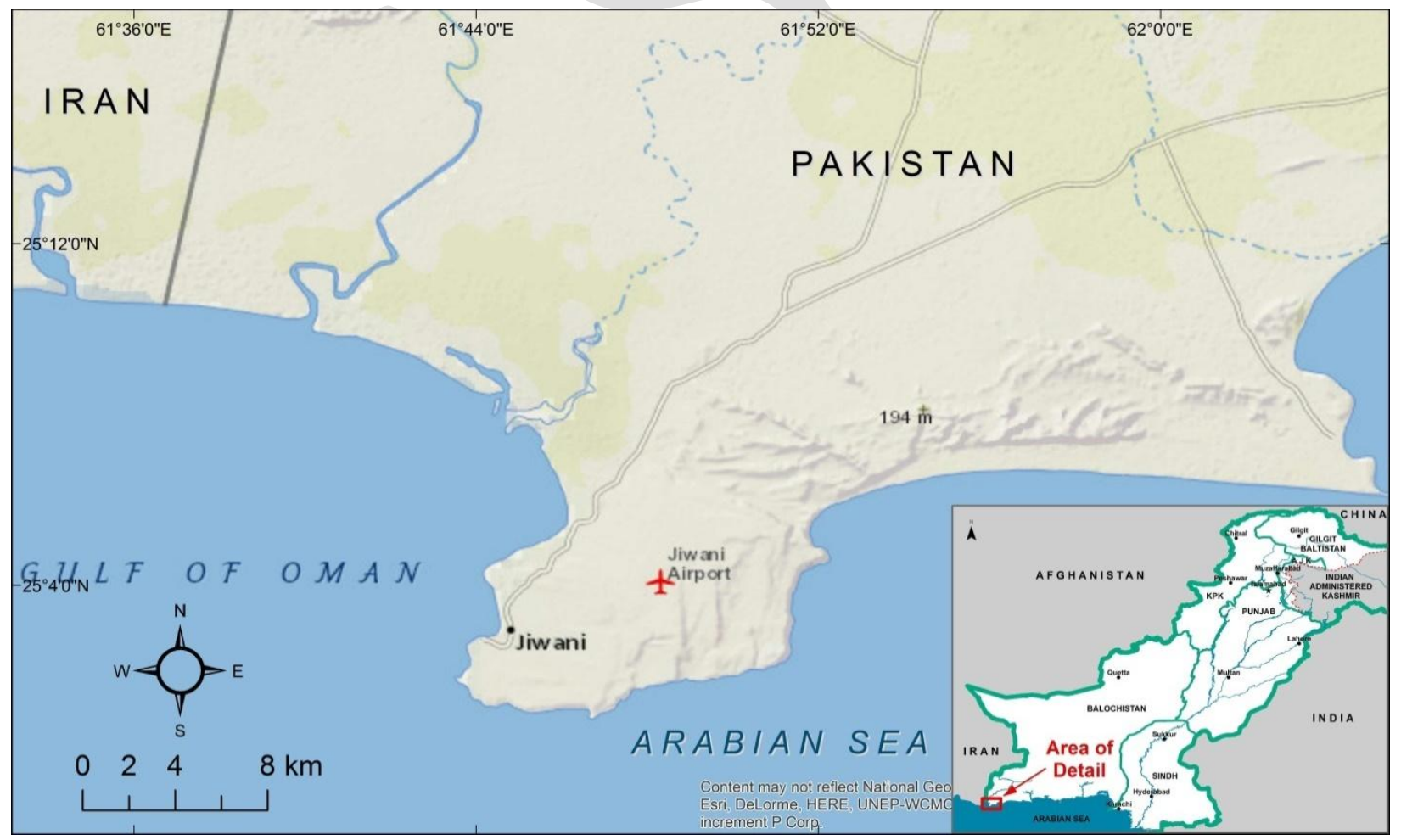

Fig 1:Map of Collection site, Jiwani, Balochistan, Pakistan 


\section{RESULTS:}

The specimens were straw to dark purple colour, attached to rocks and oyster shells by its' byssus threads. The byssus threads were closely resembledBrachidontes species. However, a septum was found, below the beak inside the shell confirming the identification towards the byssally attached mytilid genus Septifer. S. excisus has significant difference with other members of the same genus by three characters: septum, beading ribs and posterior adductor scar. This species exists from Triassic to Holocene and has been recorded from many parts of the world. This is the first record from Jiwani, Balochistan, Pakistan (figure 2).

\section{DISCUSSION:}

The specimens studied closely resemble Brachidontes species but a septum is found, below the beak inside the shell confirming the identification towards the byssally attached mytilid genus Septifer. In Septifer, the umbonal septum serves as the seat of anterior adductor muscle but the depth of the myophoric notch shows individual and species variation. The notch is always deep in some species and always shallow in others but it is not developed to same depth in all individuals of same species [1]. Septifer excisus has significant difference among other members of the same genus by three notable characters; 1) the umbonal notch in its septal shelf; 2) a well-built beading on the ribs; 3) a frequently raised posterior adductor-scar [6]. In Septifer bilocularis, the myophoric notch is either undeveloped or only shallowly developed where's in S. excisus it is always deep. The most likely paired structures formed in myophoric notches in Septifer are the anterior byssal retractor muscles. In S. bilocularis, these muscles insert into the byssal apparatus immediately posterior to the umbonal septum and probably would be in contact with the septum only when contracted. The large size of the myophoric notches and the grooves on the lateral faces of the shelves suggest that in S. excisus, the anterior byssal retractors are in more or less continuous linear contact with the septum. Umbonal shelf is only present in byssate pelecypods. In living shells, it is found in mytilid genus Septifer and in the dreissenid genera Dreissenia and Congeria [1].

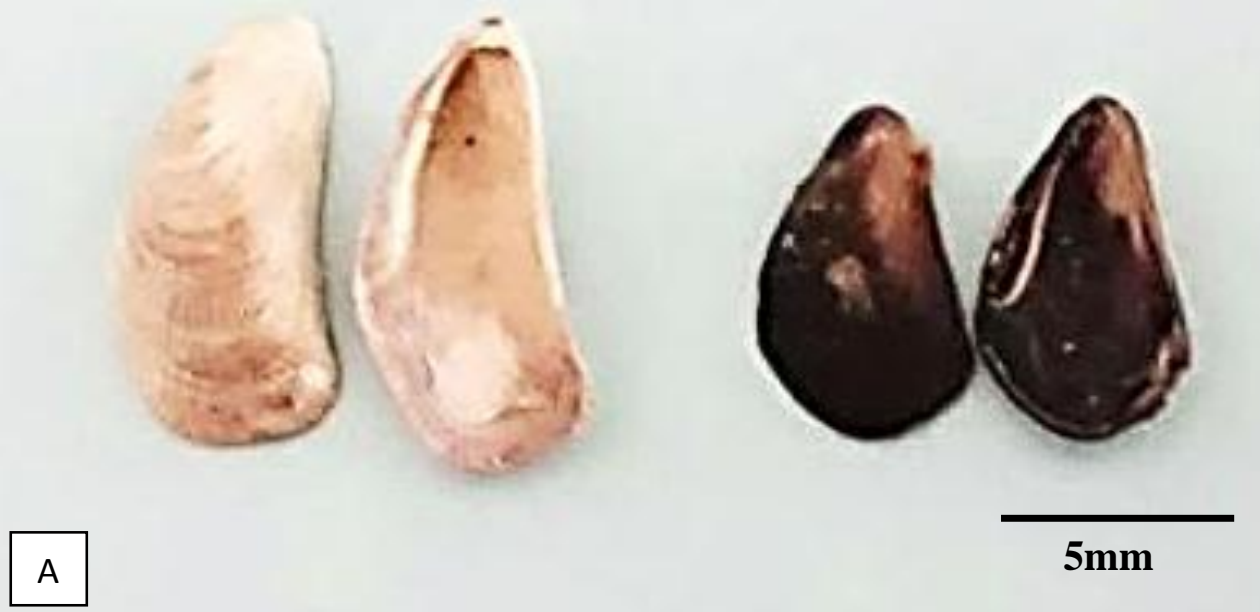




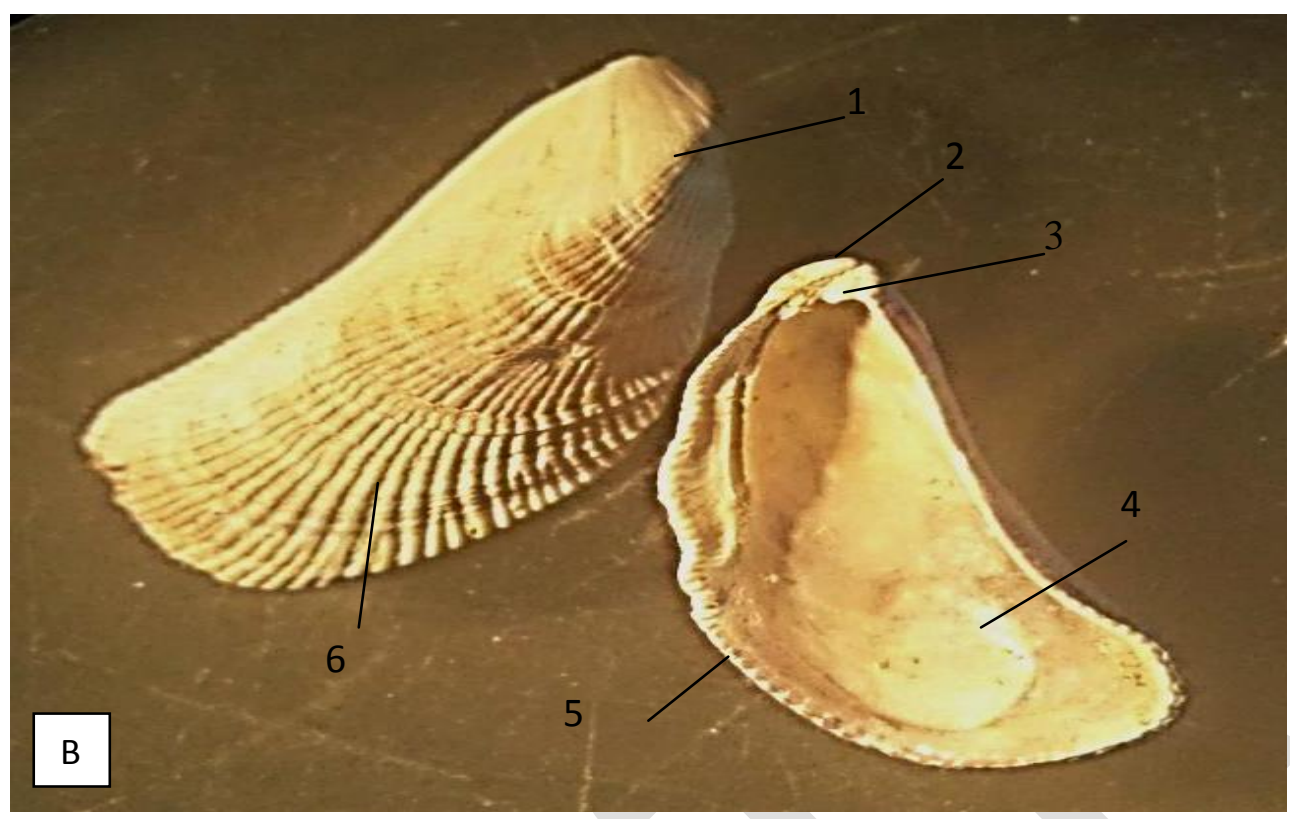

Fig 2:Septifer excisus: (A) Lower and upper valves straw and dark purple coloured shells (B) Enlarged view of labeled shells 1: Umbo; 2: Beaks; 3: Septum; 4: Posterior adductor scar; 5: Serrate (inner margin sculpture); 6: Beading ribs

\section{CONCLUSION:}

Septifer excisus has significant difference with other members of the same genus by three characters: septum, beading ribs and posterior adductor scar. This species exists from Triassic to Holocene and has been recorded from many parts of the world. This is the first record from Jiwani, Balochistan, Pakistan. This discovery will help nationally and internationally, as many of marine taxonomists and other researchers' to discover identify and report sea mussels from not only in Pakistan but all over the world.

ACKNOWLEGMENT: The authors are greatly thankful to Dr. Henk Dekker of VU University Amsterdam, Department of Medical Oncology, Amsterdam, Netherlandsfor his help in the identification of species and Mr. Asad-o-Allah for providing specimens from Balochistan, Pakistan.

\section{REFERENCES:}

1. Geological Survey U.S, 1984. U.S. Geological Survey professional paper. $6^{\mathrm{TH}}$ (ed.), Washington: U.S. G.P.O. 1228, Parts 1-4.

2. Reeve, L. A., 1857-1858. Monograph of the genus Mytilus. Conchologia Iconica 10: pls. 1-11.

3. Lamy, E., 1937. Révision des Mytilidae vivants du Muséum National d'Histoire Naturelle de Paris. J. Conchyliol. 81: 5- 71, 99-132, 169-97.

4. Kosuge, S., 1969. Fossil mollusks of Oahu, Hawaii Islands. Bull. Nat. Sci. Mus., Tokyo 12: 783-94.

5. Ostergaard, J. M., 1928. Fossil marine mollusks of Oahu. Bishop Museum. Bull. 51: 1-32.

6. Pauley, G., 1996. New records and synonymies of Hawaiian bivalves. Bishop Museum. Occas. Pap. 45:18-29.

7. McKenna, S. A., Allen, G. R, Suryadi, S., 2002. A Marine Rapid Assessment of the Raja Ampat Islands, Papua Province, Indonesia. RAP Bulletin of Biological Assessment 22. Conservation International, Washington DC. 
8. Lee, S-C and Chao, S-M., 2004. Shallow-water Marine Shells from Kenting National Park, Taiwan. Coll. and Res. 17:33-57.

9. Paulay, G., 2003. Marine Bivalvia (Mollusca) of Guam. Micronesica, 35-36: 218-243p.

10. Harding,S., Randriamanantsoa,B., Hardy, $T$ and Curd, A., 2006. Coral Reef Monitoring and Biodiversity Assessment to support the planning of a proposed MPA at Andavadoaka. A combine report of Wildlife Conservation Society, Marine Program, BP 8500 Soavimbahoaka, Antananarivo 101, Madagascar and Blue Ventures, 52 Avenue Road, London, UK.

11. Tan, S. K and Yeo, R. K. H., 2010. THE INTERTIDAL MOLLUSCS OF PULAU SEMAKAU: PRELIMINARY RESULTS OF "PROJECT SEMAKAU. NATURE IN SINGAPORE, 3: 287-296p.

12. Tan, S. K and Woo, H. P. M., 2010. A PRELIMINARY CHECKLIST OF THE MOLLUSCS OF SINGAPORE. Published by the Raffles Museum of Biodiversity Research and Department of Biological Sciences Faculty of Science National University of Singapore. ISBN 978-981-08-5834-6 (online).

13. Picardal, R. M and Dolorosa, R. G., 2014. The molluscan fauna (gastropods and bivalves) and notes on environmental conditions of two adjoining protected bays in Puerto Princesa City, Palawan, Philippines. Journal of Entomology and Zoology Studies; 2 (5): 72-90.

14. Tan, S. K and Low, M. E. Y., 2014. Checklist of the Mollusca of Cocos (Keeling) / Christmas Island ecoregion. RAFFLES BULLETIN OF ZOOLOGY Supplement No. 30: 313-375.

15. Nawrot, R., Chattopadhyay, D., Zuschin, M., 2015. what guides invasion success? Ecological correlates of arrival, establishment and spread of Red Sea bivalves in the Mediterranean Sea. Diversity and Distributions. 21, 1075-1086.

16. Solene, M., Morris, O., Purchon, R. D., 2017.THE MARINE SHELLED MOLLUSCA OF WEST MALAYSIA AND SINGAPORE PART 3, BIVALVIA. Journal of Molluscan Studies, 47 (3): 322327. https://doi.org/10.1093/oxfordjournals.mollus.a065574

17. Ebied M. A-B and Aly, M. F, 2004. Cytogenetic studies on metaphase chromosomes of six bivalve species of families mitilidae and veneridae (Nucinelloidea, Mollusca). Cytologia. 69 (3), 261-273p.

18. Huber,M., 2015. Septifer excisus (Wiegmann, 1837). In: MolluscaBase (2015). Accessed through: World Register of Marine Species (WoRMS). 